\title{
The distribution of Eukoenenia mirabilis (Palpigradi: Eukoeneniidae): a widespread tramp
}

\author{
Mark S. Harvey ${ }^{1}$, Frantisek Štáhlavský ${ }^{2}$ and Pieter D. Theron ${ }^{3}$ \\ 'Department of Terrestrial Invertebrates, Western Australian Museum, Locked Bag 49, \\ Welshpool DC, Western Australia 6986, Australia. \\ Department of Zoology, Charles University, Vinièná 7, CZ-128 44 Prague 2, Czech Republic. \\ 'School of Environmental Sciences and Development, North-West University, Potchefstroom Campus, \\ Potchefstroom, P. Bag X6001, Potchefstroom 2520, South Africa.
}

\begin{abstract}
We report on the discovery of populations of the palpigrade Eukoenenia mirabilis (Grassi and Calandruccio, 1885) in South Africa and Western Australia, and compile known distributional records for the species. It is found to be widespread throughout the Mediterranean region, with additional populations occurring in Madagascar, South Africa, Chile and southern Australia. Accidental synanthropic introductions are the most likely cause of these additional records.
\end{abstract}

\section{INTRODUCTION}

Members of the arachnid order Palpigradi represent one of the more obscure and poorlyknown arachnid orders with only 79 species named in six genera and two families (Harvey 2003; Mayoral and Barranco 2002). Their phylogenetic affinities are poorly known and several competing hypotheses exist regarding their systematic placement. For example, Hammen (1977, 1989) treated palpigrades as members of the Epimerata along with the mite taxon Actinotrichida. Weygoldt and Paulus (1979) and Weygoldt (1998) regarded them as sister to Solifugae, Chelonethi (Pseudoscorpiones), Opiliones, Ricnulei and Acari. Shultz (1990) and Wheeler and Hayashi (1998) treated them as sister to the Tetrapulmonata (Araneae, Amblypygi, Schizomida and Uropygi).

The most abundant palpigrade genus, Eukoenenia Börner, is found in many parts of the world and is represented by over 60 species (Harvey 2003). Two species of this genus, E. mirabilis (Grassi and Calandruccio, 1885) and E. florenciae (Rucker, 1903), are widely distributed and appear to consist of largely parthenogenetic populations that have probably been inadvertently dispersed through human agency (Walter and Condé 1997) Eukoenenia mirabilis is widely distributed in north Africa and southern Europe, and has also been recorded from other parts of the world, including Madagascar (Rémy 1950, 1960), Chile (Condé 1974) and South Australia (Savory 1935). The Malagasy and Chilean records were made by experienced palpigrade taxonomists but there has long been suspicion regarding the identity of the Australian populations. We have examined and confirmed the identity of the South Australian palpigrade populations and here report on the recent discovery of E. mirabilis in South Africa and Western Australia. We also discuss the known distribution of this species and present a distribution map depicting the known populations.

The specimens examined for this study are lodged in the South Australian Museum, Adelaide (SAM) and the Western Australian Museum, Perth (WAM). Specimens were examined with an Olympus $\mathrm{BH}-2$ compound microscope by temporarily mounting the specimens on microscope slides in glycerol after clearing in very dilute lactic acid. After study they were returned to $75 \%$ ethyl alcohol in microvials.

\section{Eukoenenia mirabilis (Grassi and Calandruccio,} 1885)

Figures 1-4

Koenenia mirabilis Grassi and Calandruccio, 1885 165.

Eukoenenia mirabilis (Grassi and Calandruccio): Harvey 2003: 156-157 (full synonymy).

\section{Material examined}

Australia: South Australia: 1 \&, 1 \& (stage B), Adelaide (SAM 1991693-4; B. Condé det.); 4 \&, Glen Osmond [3457'S, 138 38'E], March 1933, August 1933, 11 May 1934, H. Womersley (SAM); 4 9, Glen Osmond [ $34^{\circ} 57^{\prime} \mathrm{S}, 138^{\circ} 38^{\circ} \mathrm{E}$ ], 27 July 1935, 4 August 1935, 3 September 1950, 9 October 1950, R.V. Southcott (SAM); 7 specimens (including 39 ), Glen Osmond, Birksgate $\left[34^{\circ} 57^{\prime} \mathrm{S}, 138^{\circ} 38^{\circ} \mathrm{E}\right]$, under stones, 31 August 1975, 13 September 1975, R.V. 
Southcott and A.M.S. (SAM); 19 , Glen Osmond, Woodley Vineyard $\left[34^{\circ} 57^{\prime} \mathrm{S}, 138^{\circ} 38^{\prime} \mathrm{E}\right], 16$ November 1952, R.V. Southcott (SAM); 2 specimens (chelicerae only), Mt Osmond [34 57'S, 138 39'E], 16 April 1933, H. Womerslev (SAM); 7 9. Mt Osmond [34 57'S, 138 $3^{\circ} \mathrm{E}$ ], 30 August 1953, R.V. Southcott (SAM); 7 specimens, Waterfall Gully $134^{\circ} 57^{\prime} \mathrm{S}$, $138^{\circ} 40^{\prime} \mathrm{E}$ ], north-eastern bank, pond, ex moss and soil, 1968, D.C. Lee (SAM N1991686-94); Western Australia: 13 \&, Wungong Dam 132\%11'41"S, $\left.116^{\circ} 03^{\prime} 33^{\prime \prime} \mathrm{E}\right]$, on underside of rocks embedded in soil, 26 August 2003, M.S. Harvey, F. Štáhlavský (WAM T55860-55861); 2 ㅇ, Wungong Dam, hillside above carpark, $32^{\circ} 11^{\prime} 38^{\prime \prime} S, 116^{\circ} 03^{\prime} 36^{\prime \prime} \mathrm{E}$, under rocks, 12 July 2004, M.S. Harvey, J. Waldock, R. Engel, T. Moulds (WAM T62256); 2 \%, Wungong Dam, above trail to dam $\left[32^{\circ} 11^{\prime} 40^{\prime \prime} \mathrm{S}, 116^{\circ} 03^{\prime} 37^{\prime \prime} \mathrm{E}\right]$, under rocks, 12 July 2004, J.M. Waldock (WAM T62259). South
Africa: North-West Province: 69 , Botanical Garden, North-West University, Potchefstroom Campus [26 $\left.40^{\prime} \mathrm{S}, 27^{\circ} 05^{\prime} \mathrm{E}\right]$, from underside of stones, and from leaf litter, P.D. Theron (WAM 99/ 1082-1087).

\section{Remarks}

Identification of female specimens is confirmed by the presence of 5-6 stout glandular setae on sternites $\mathrm{V}$ and VI, and by the presence of a single blade in the lateral organ. This combination of features conforms to that described for E. mirabilis by previous authors such as Silvestri (1905) and Condé (1991), who noted very slight differences between different populations of $E$. mirabilis.

The anterolateral margin of the prosoma bears a single pair of ovoid lateral organs in specimens from all collections. These blades provide an
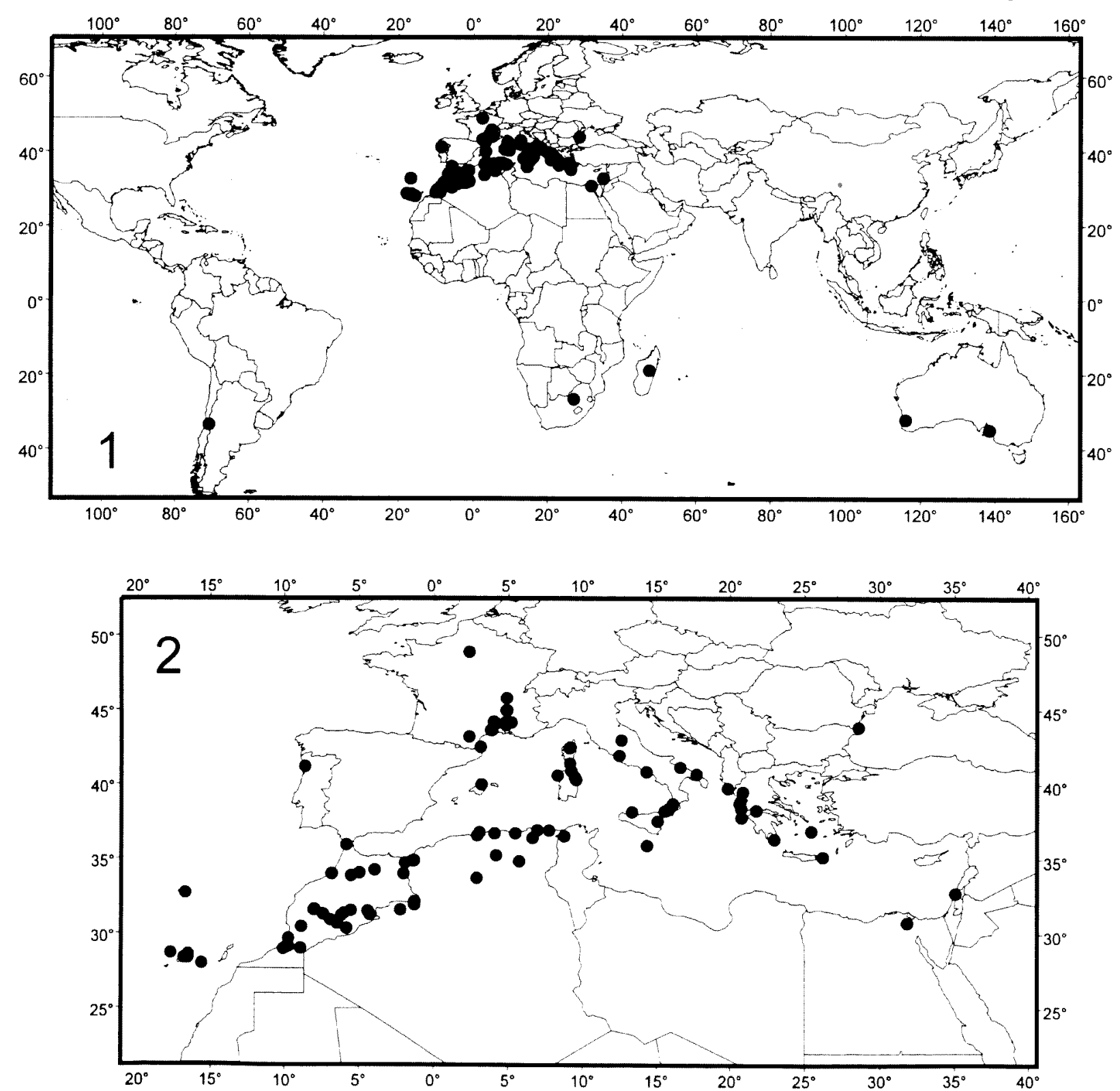

Figures 1-2 Maps showing known distribution records of Eukoenenia mirabilis. 1, total records. 2, detail depicting records in Mediterranean region. 
important feature for the identification of palpigrades. Multiple blades, ranging from 2 to 13 blades, in the lateral organ can be found in adults of most species of Eukoenenia, some species of Koeneniodes (K. deharvengi, K. leclerci, K. notabilis and $K$. spiniger) and all species of Leptokoenenia, Prokoenenia and Triadokoenenia. The number of blades is fairly consistent within a single species, but minor variations in blade number have been recorded, both within populations and on either side of an individual specimen. The presence of only a single blade is a feature shared by only a few species, including E. mirabilis, E. angusta hindua Condé, 1989, E. berlesei (Silvestri, 1903), E. gadorensis Mayoral and Barranco, 2002, E. hesperia (Rémy, 1953), E. madeirae Strinati and Condé, 1995, E. necessaria Rémy, 1960, Allokoenenia afra Silvestri, 1913, Koeneniodes berndi Condé, 1988, K. frondiger Rémy, 1950 (Condé 1994; Rémy 1958), K. madecassus Rémy 1950 (Condé 1990; Rémy 1961) and K. malagasorum Rémy 1960. The adults and, where known, the immatures of all known species of other palpigrade genera (Leptokoenenia, Prokoenenia and Triadokoenenia) bear more than one blade.
The subadult stages of two of these species ( $E$. mirabilis and Koeneniodes frondiger) are known and, like the adults, bear a single blade in the lateral organ (Rémy 1952, 1958). Other immatures, such as Allokoenenia? sp. (Condé 1992), also bear a single blade only. The immature stages of some other Eukoenenia species bear just a single blade, but the adults bear multiple blades: E. condei Orghidan, Georgesco and Sârbu, 1982, E. florenciae (Rucker, 1903) (the "youngest known" stage), E. lienhardi Condé, 1989 (stage "immature A"), and various unidentified Eukoenenia species (Condé 1994; Rémy 1959, 1960). It may be possible that the presence of a single blade is a paedomorphic trait amongst palpigrades.

\section{Distribution}

Eukoenenia mirabilis was first recorded from Sicily (Grassi 1886; Grassi and Calandruccio 1885) and has been subsequently reported from many other localities in the Mediterranean region ranging from the Canary Islands and Madeira in the west to Israel in the east (Figures 1, 2). The most northerly records are from France but these are based upon specimens collected from artificial environments
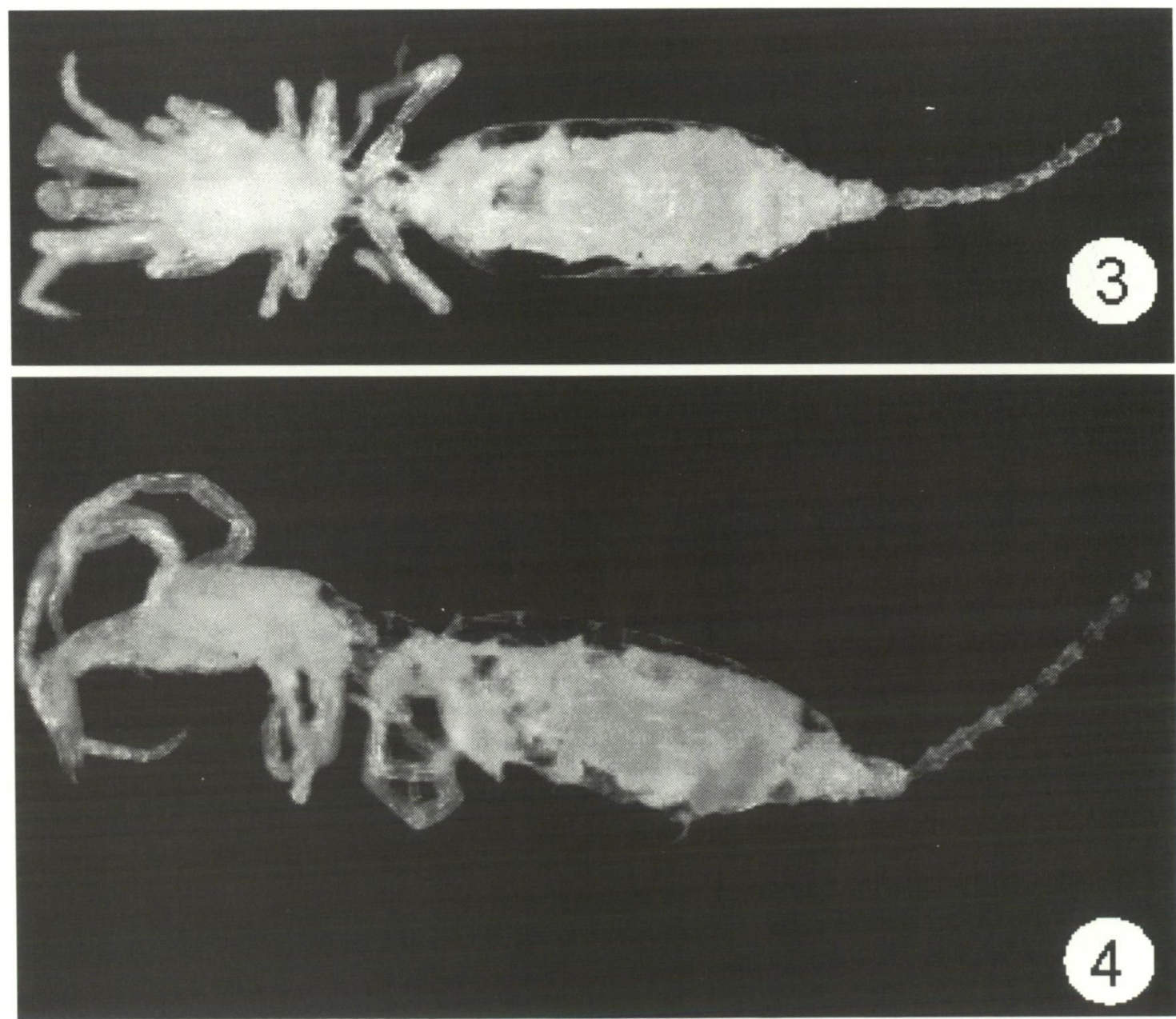

Figures 3-4 Eukoenenia mirabilis, female (WAM T55860): 3, dorsal aspect. 4, lateral aspect. Note that some of the flagellum has been lost. 
such as greenhouses. Outside of the Mediterranean region, E. mirabilis has been previously found in Chile, Madagascar and South Australia. The only Chilean record is from San Bernardo (Cekalovic 1984; Condé 1974), whilst in Madagascar, E. mirabilis has only been found in the vicinity of Antananarivo (Legendre 1972; Rémy 1950, 1960). Eukoenenia mirabilis was first recorded from Australia by Savory (1935), who later (Savory 1964) stated that "...in 1933 Koenenia mirabilis was found on the lower slopes of Mount Osmond, Adelaide, whither it had most probably been imported." Lee and Southcott (1979) also recorded its presence in the Lofty Ranges on the outskirts of Adelaide, where it can be locally common (the late D.C. Lee, pers. comm.). MSH found many specimens of $E$. mirabilis in the collections of the South Australian Museum collected by $\mathrm{H}$. Womersley, an avid and accomplished collector of minute invertebrates in the Adelaide region (Southcott 1964), the earliest of which was taken in March 1933 at Glen Osmond. These specimens appear to represent the source of Savory's record of E. mirabilis which were presumably conveyed to him by Womersley. Since that time many specimens have been collected by Womersley, R. Southcott and D.C. Lee in the eastern suburbs of Adelaide (see list of specimens examined above) suggesting that the species is firmly established in the area.

To these records we now add single localities from Western Australia and South Africa. The Western Australian locality is a natural eucalypt woodland situated on the outskirts of Perth dominated by Marri (Corymbia calophylla) with a heath understorey. The palpigrades were found on the underside of stones and rocks that were deeply embedded in the surrounding soil, and the palpigrades moved quickly when disturbed. The South African specimens were collected from the Potchefstroom Campus of the North-West University. The first specimens were recovered from the upper soil in an undisturbed Acacia karroo biotope outside of the Botanical Garden. Subsequent sampling revealed fair members of palpigrades running freely on the undersides of stones. Large numbers of isotomid collembolans were noted and they are probably preyed on by the palpigrades.

The discovery of E. mirabilis in Western Australia and South Africa, and the confirmation of the identity of the South Australian specimens demonstrates that $E$. mirabilis is more widely distributed in the southern hemisphere than previously suspected. It also suggests that it may eventually be found in other localities. For example, Forster and Forster (1999) noted the presence of at least two species of palpigrades in New Zealand, but at present the specimens cannot be located ( $P$. Sirvid, pers. comm.). Therefore, their identification remains a mystery.
All of the records from the southern continents are situated in Mediterranean climates between $18^{\circ} \mathrm{S}$ and $35^{\circ} \mathrm{S}$, and appear to represent accidental introductions through human agency. The earliest recorded occurrence of $E$. mirabilis from outside the Mediterranean region is from Glen Osmond in 1933. The natural distribution of E. mirabilis in the Mediterranean region is impossible to ascertain as centuries of sea-faring trading commerce in the region have probably dispersed these small soildwelling animals far beyond their original natural range.

\section{ACKNOWLEDGEMENTS}

We wish to gratefully acknowledge the assistance of David Hirst for his assistance in allowing access to the collections of the South Australian Museum, Adelaide, and Volker Framenau (Western Australian Museum, Perth) and an anonymous referee for their comments on a draft of the manuscript.

\section{REFERENCES}

Cekalovic K., T. (1984). Catalogo de los Pseudoscorpiones y Palpigradi de Chile (Chelicerata). Boletín de la Sociedad de Biología de Concepción 55: 7-35.

Condé, B. (1974). Palpigrades du Chile. Revue d'Ecologie et de Biologie du Sol 11: 449-455.

Condé, B. (1988). Nouveaux Palpigrades de Trieste, de Slovénie, de Malte, du Paraguay, de Thailande et de Bornéo. Revue Suisse de Zoologie 95: 723-750.

Condé, B. (1989). Palpigrades (Arachnida) endogés de l'Inde et de Sumatra. Revue Suisse de Zoologie 96: 411-424.

Condé, B. (1990). Palpigrades endogés de Singapour et de l'Indonésie. Revue Suisse de Zoologie 97: 681-697.

Condé, B. (1991). Le Palpigrade Eukoenenia mirabilis dans les Archipels macaronésiens. Revue d'Écologie et de Biologie du Sol 28: 119-124.

Condé, B. (1992). Un Palpigrade énigmatique de Thailande avec une breve revue des grandes divisions de l'ordre. Revue Suisse de Zoologie 99 : 741-746.

Condé, B. (1994). Palpigrades cavernicoles et endogés de Thailande et des Célèbes ( $2^{\mathrm{i}}$ note). Revue Suisse de Zoologie 101: 233-263.

Forster, R.R. and Forster, L.M. (1999). Spiders of New Zealand and their Worldwide Kin. University of Otago Press and Otago Museum: Dunedin.

Grassi, B. (1886). I progenitori dei Miriapodi e degli Insetti Memoria $V$. Intorno ad un nuovo Aracnide artrogastro (Koenenia mirabilis) rappresentante di un nuovo ordine (Microthelyphonida). Bollettino della Società Entomologica Italiana 18: 153-172.

Grassi, B. and Calandruccio, S. (1885). Intorno ad un nuovo Aracnide Artrogastro (Koenenia mirabils [sic]) che crediamo rappresentante d'un nuovo ordine (Microteliphonida). Naturalista Siciliano 4: 127-133, 162-168. 
Hammen, L. van der (1977). A new classification of Chelicerata. Zoölogische Mededelingen 51: 307-319.

Hammen, L. van der (1989). An Introduction to Comparative Arachnology. SPB Academic Publishing: The Hague

Harvey, MS. (2003). Catalogue of the Smaller Arachnid Orders of the World: Amblypygi, Uropygi, Schizomida, Palpigradi, Ricinulei and Solifugae. CSIRO Publishing: Melbourne.

Lee, D.C. and Southoott, R.V. (1979). Spiders and other arachnids of South Australia. In B.E. Leonard (ed.), South Australian Year Book, pp. 29-43. Australian Bureau of Statistics: Adelaide.

Legendre, R. (1972). Les Arachnides de Madagascar. In R. Battistini and G. Richard-Vindard (eds), Biogeography and Ecology in Madagascar, pp. 427457. Junk: The Hague.

Mayoral, J.G. and Barranco, P. (2002). Descripción de una nueva Eukoenenia Börner, 1901 del Sureste Ibérico (Arachnida, Palpigradi, Microthelyphonida). Revista Ibérica de Arachnología 6: 129-134.

Rémy, P.A. (1950). Palpigrades de Madagascar Mémoires de I'Institut Scientitique de Madagascar, Série A 4: 135-164.

Rémy, P.A. (1952). Palpigrades de l'ile de la Réunion. Mémoires de I'Institut Scientifique de Madagascar, Série A 7:69-79.

Rémy, P.A. (1953). Description d'un nouveau palpigrade d'Afrique occidentale française. Bulletin du Muséum National d'Histoire Naturelle, Paris (2) 25:86-89.

Rémy, P.A. (1958). Palpigrades de l'île Maurice. Mauritius Institute Bulletin 5: 94-102.

Rémy, P.A. (1959). Palpigrades et Pauropodes du Natal (nouvelles récoltes du Dr R.F. Lawrence). Bulletin du Muséum National d'Histoire Naturelle, Paris (2) 31: $256-260$.

Rémy, P.A. (1960). Palpigrades de Madagascar. II. Mémoires de l'Institut Scientifique de Madagascar, Série A 13: 33-66.

Rémy, P.A. (1961). Les Palpigrades de Ceylan et leur ecologie. Revue Française d'Entomologie 28: 112-119.
Rucker, A. (1903). A new Koenenia from Texas. Quarterly Journal of Microscopical Science (n. s.) 47: 215-231.

Savory, T.H. (1935). The Arachnida. Edward Arnold and Co.: London.

Savory, T.H. (1964). Arachnida. Academic Press: London.

Shultz, J.W. (1990). Evolutionary morphology and phylogeny of Arachnida. Cladistics 6: 1-38.

Silvestri, F. (1903). Fauna Napoletana. Descrizione preliminare di due nuove specie di Koenenia trovate in Italia. Annuario del Museo Zoologico della $R$. Università di Napoli 1(11): 1-2

Silvestri, F. (1905). Note arachnologiche I. Specie Italiane del genere Koenenia con descrizione delle femmine giovani e del maschio della K. mirabilis. Redia 2: 239 253.

Silvestri, F. (1913). Novi generi e specie de Koeneniidae (Arachnida, Palpigradi). Bollettino di Laboratorio di Entomologia Agraria Portici 7: 211-217.

Southcott, R.V. (1964). Obituary and bibliography of Herbert Womersley. Records of the South Australian Museum 14: 603-632.

Strinati, P. and Condé, B. (1995). Grottes et Palpigrades de Madere. Mémoires de Biospéologie 22: 161-168.

Walter, D.E. and Condé, B. (1997). Eukoenenia florenciae Rucker, 1903 (Arachnida: Palpigradi: Eukoeneniidae), Australia's second record of a cosmopolitan all-female species of palpigrade. Australian Entomologist 24: 164.

Weygoldt, P. (1998). Evolution and systematics of the Chelicerata. Experimental and Applied Acarology 22: 63-79.

Weygoldt, P. and Paulus, H.F. (1979). Untersuchungen zur Morphologie, Taxonomie und Phylogenie der Chelicerata. II. Cladogramme und die Entfaltung der Chelicerata. Zeitschrift für Zoologische Systematik und Evolutionsforschung 17: 177-200.

Wheeler, W.C. and Hayashi, C.Y. (1998). The phylogeny of the extant chelicerate orders. Cladistics 14: 173192.

Manuscript recowed 26 May 2005; accepted 25 May 2006 